\title{
Climate Change Concerns of Saudi Arabian Farmers: The Drivers and Their Role in Perceived Capacity Building Needs for Adaptation
}

\author{
Bader Alhafi Alotaibi 1,*(D), Azhar Abbas ${ }^{2} \mathbb{D}$, Raza Ullah ${ }^{2}$, Roshan K. Nayak ${ }^{3}$, Muhammad I. Azeem ${ }^{1} \mathbb{D}$ \\ and Hazem S. Kassem $1, *$ iD \\ 1 Department of Agricultural Extension and Rural Society, College of Food and Agriculture Sciences, \\ King Saud University, Riyadh 11451, Saudi Arabia; miazeem@outlook.com \\ 2 Institute of Agricultural and Resource Economics, University of Agriculture, Faisalabad 38040, Pakistan; \\ azhar.abbas@uaf.edu.pk (A.A.); raza.khalil@uaf.edu.pk (R.U.) \\ 3 Division of Agricultural and Natural Resources, University of California, 2801 2nd Street, \\ Davis, CA 95616, USA; rknayak@ucanr.edu \\ * Correspondence: balhafi@ksu.edu.sa (B.A.A.); hskassem@ksu.edu.sa (H.S.K.)
}

check for updates

Citation: Alotaibi, B.A.; Abbas, A.; Ullah, R.; Nayak, R.K.; Azeem, M.I.; Kassem, H.S. Climate Change

Concerns of Saudi Arabian Farmers: The Drivers and Their Role in Perceived Capacity Building Needs for Adaptation. Sustainability 2021, 13, 12677. https://doi.org/10.3390/ su132212677

Academic Editor: Luisa F. Cabeza

Received: 29 September 2021

Accepted: 12 November 2021

Published: 16 November 2021

Publisher's Note: MDPI stays neutral with regard to jurisdictional claims in published maps and institutional affiliations.

Copyright: (c) 2021 by the authors. Licensee MDPI, Basel, Switzerland. This article is an open access article distributed under the terms and conditions of the Creative Commons Attribution (CC BY) license (https:/ / creativecommons.org/licenses/by/ $4.0 /)$.

\begin{abstract}
Climate change is a serious threat to the sustainability of global agriculture and food supply that necessitates taking appropriate action for building resilient food production systems and preserving rural economies. In this regard, farmers' beliefs and concerns about the effects of climate change on agriculture may influence their adoption of adaptation and mitigation practices to address this emerging issue. This work was undertaken to evaluate farmers' level of concern about climate change in the Jazan province of Saudi Arabia. The study also explored the role of various socioeconomic indicators in shaping farmers' concerns and highlights various capacity-building initiatives that can be applied at the community level for effective adaptation. Ordered logistic regression was used to study the relationship between farmers' level of concern and their need for capacity-building initiatives to tackle climate change. Results indicated that insect infestation is the farmers' top concern, followed by higher crop-diseases incidence and drought. Regression analysis revealed that farmers' income is a major factor that reduces their concern for insect infestation and crop disease while increases concern for drought. Credit access and information availability have a mixed impact on the farmers' concern level. Capacity-building initiatives deemed necessary included establishing frequent contacts with extension personnel, timely warnings on droughts and other natural hazards, the training of farmers and extension workers, easy credit facilities, improvement in rural infrastructure and creation of awareness to address specific concern stimulus.
\end{abstract}

Keywords: climate change; concern; indicator; Saudi Arabia; adaptation

\section{Introduction}

Climate change is a serious global issue with implications in every domain of human life [1-3]. The evidence suggests that global warming and a change in precipitation patterns will be experienced as a result of ongoing change in the climate. It is expected that the global average temperatures may rise by $1.4-5.8^{\circ} \mathrm{C}$ by the end of 2100 [4]. Shifts in seasonal water availability throughout the year are likely to aggravate different regions [5]. It is also predicted that the frequency and intensity of extreme weather events like drought and flooding will also increase given weaker coping capacity and poor adaptation planning particularly in developing countries [6,7].

Many studies have predicted a range of harmful impacts due to climate change that potentially threaten global agricultural systems and food security on a fundamental level $[3,8,9]$. The extent and productivity of both rain-fed and irrigated agriculture will be affected. A greater proportion of the population is projected to experience the potential 
negative impacts of the climate change and, in many regions, there will be a decrease in crop productivity [10-12]. Projections suggest that at a temperature increase of $2{ }^{\circ} \mathrm{C}$, around 540-590 million people will become undernourished [13]. Some regions of the world could lose up to $6 \%$ of their national Gross Domestic Product (GDP) due to climate-induced water scarcity [14]. The regions that are already vulnerable to food insecurity and rural poverty will be the most-adversely affected [15].

Saudi Arabia is one of the largest countries with an arid climate [4,16]. Within this country's area, temperatures can rise above $50{ }^{\circ} \mathrm{C}$ due to climatic changes [4] that have already taken their effect. A study estimated that there was a $1.9^{\circ} \mathrm{C}$ increase in average temperature over the last 50 years in the Kingdom [17]. The rate of increase was higher $\left(0.72{ }^{\circ} \mathrm{C}\right.$ per decade) in the dry season as compared to the wet season ( $0.51{ }^{\circ} \mathrm{C}$ per decade) [18]. Several studies predict that the average temperature in the Kingdom can further elevate 2 to $4{ }^{\circ} \mathrm{C}$ by the end of 2100 as a result of climate change [19-21].

Rainfall in Saudi Arabia is extremely limited. Across the country, the long-term average precipitation is about $100 \mathrm{~mm}$ per annum. In the southern part of the country, rainfall goes below $100 \mathrm{~mm}$ while in the north, it varies between 100 to $200 \mathrm{~mm}$ per annum. In the western part, however, rainfall can even rise up to $500 \mathrm{~mm}$ annually [4]. A significant change in rainfall has not been observed over the last 50 years [17]. However, future rainfall projections suggest a decrease in rainfall in many parts of the Kingdom [21,22]. However, it is worth-mentioning that intense and frequent precipitation events in Saudi Arabia are rare [23]. The Kingdom lacks recurrent rivers and permanent water bodies. The United Nations have classified countries of the Gulf Cooperation Council (GCC) as water-scarce nations [24]. According to Water Resources Institute, 14 out of 33 countries that are most likely to be water-stressed in 2040 are located in the Middle East, where Saudi Arabia is ranked at 9 th position [25].

Due to its arid climate, the Kingdom is highly vulnerable to the negative impacts of climate change. A 3 to $5{ }^{\circ} \mathrm{C}$ increase in temperature would have dire consequences for the agriculture and other sectors of the economy $[16,26]$. Due to climate change, significant impacts on agriculture have been reported by a number of studies [26-28]. It has been estimated that crops' irrigation water requirements would increase by 602 and 3122 million cubic meters at temperature increases of 1 and $5{ }^{\circ} \mathrm{C}$, respectively [29]. This is in conformity to a study which reports that maintaining the current levels of crop production, global warming may lead to increase in agricultural water demand by about 5 to $15 \%$ [20]. Lack of water may result in significant yield losses as about $90 \%$ of agriculture in the Kingdom is irrigated [30]. The agriculture sector has the largest share of annual water use that is about 70\% [17]. A study showed that climate suitability for date palm production in the Kingdom will be significantly reduced [26]. Another study reported that many farmers observed unusually early date palm blooming in 2010 [31]. Moreover, global warming will particularly affect the diurnal desert animals by reshaping their population and distribution in the desert [19].

Climate change severely affects crop production owing to its sensitivity to variations in precipitation and temperature. Plant diseases and water shortage have resulted in a decline in the total annual income of date palm growers in the Middle East from 1990 to 2000 [32]. A reduction in food production would increase food prices at the domestic level with implications for food imports [33]. Water scarcity further increases the vulnerability of the region to the fast-happening climatic changes [34]. A recent study indicates that reduction in crop yields ranges between 5 and 25\% with a one-degree Celsius increase in temperature. The Jazan region has been already experiencing climate change manifestations in the form of land degradation in the coastal areas, rising temperatures, droughts, soil erosion, altered rainfall patterns, floods, and changes in weed species, and their geographical distribution [35]. In a previous study, Jazan farmers indicated that they are very concerned about increased drought, floods, and appearance of weeds.

Saudi Arabia is one of the countries that are addressing climate change in a serious manner and putting suitable measures in place [17]. One key aspect of various climate 
change adaptation approaches is that farmers and growers at the grassroots level are well aware of this global issue and are using sustainable agricultural practices to effectively address this issue. However, farmers with different socioeconomic characteristics and life experiences may conceptualize climate change issues in different ways that in turn would affect their ability to implement appropriate adaptation practices for building resilience against undesirable climatic impacts.

The present study was undertaken with the objective of identifying the major concerns of the farming community regarding climate change and exploring various determinants that affect their understanding of climate change. Additionally, an account of farmers' beliefs about climate change along with the estimated impacts of climate change concerns on the perceived capacity-building measures/initiatives needed to cope with the ill impacts of climate change is also presented.

The study findings offer insights into the adaptation behavior of the farmers in relation to different climatic concerns. In addition, the findings are expected to assist in the design of appropriate extension interventions to help farmers implement relevant adaptation and mitigation practices for combating climate change in Saudi Arabia. Moreover, this study provides answers to the following research questions:

- What are the major concerns of farm households about climate change and how those concerns are influenced by various socioeconomic factors of the farmers?

- What beliefs do farmers of the study area have about the nature and impacts of climate change?

- What capacity-building initiatives are deemed useful by respondent farmers for effective adaptation to climate change and how the choice of various capacity-building options is influenced by the nature of climate change stimulus?

The first question is answered by an extensive review of literature along with an empirical estimation of concern level by ranking them and finding covariates of concern level through ordered logit model. The same procedure of ranking is adopted to answer the second and the third question while logit is used to explore the covariates of the various capacity-building options.

\section{Literature Review and Development of Research Framework}

There are a range of drivers and factors that have a significant bearing on the farmers' concerns for climate change with different dynamics leading to adaptation concerns [36]. The concerns for climate change among people are thought to emanate from the risk attached with extreme events such as, inter alia, droughts, floods, cyclones, heat waves, avalanches $[33,34,37]$. People form their concern level with their exposure to risk such as the events associated with climate change. In this regard, demographic, socioeconomics, geoenvironmental and institutional characteristics and features possessed/faced by individuals would play a greater role in affecting their concerns for such stimuli as well as their perceived interventions to enable them effectively face and cope the vagaries of such events through person-specific or community-based approaches [38-41].

We posit such initiatives/interventions as capacity-building options deemed effective and needed to equip community members for better preparing them to mitigate and cope climate change risks. This work presents an integrated framework to portray the significance of concerns for climate change among farmers as well as the direly-needed capacity building initiatives deemed appropriate by the end-users, i.e., the farming community. Nevertheless, the factors related with the concerns and capacity-building needs are not all-inclusive rather represent those identified by a particular set of a community, although, a considerable cross-cultural variation is reported in both the intensity of collective public concerns as well as general willingness on addressing the issue [42,43]. One of the major factors related with concern for climate change is shown to be awareness level as noted by [42] who show that awareness and concern have grown throughout the world in the last two to three decades. 
The Climate Change Risk Perception Model (CCRPM) given by [44] integrates four key theoretical dimensions to express concern/perception for climate change taking into account 'cognitive', 'experimental', 'sociodemographic', and 'sociocultural' factors. Taking insights from this model, the study in hand has taken lead to link some of these factors to express the level of concern among the study area respondents. In this regard, age and income are used to draw some insights on the concern level apart from education. On the role of knowledge, contrasting views are found about its impact on concern level thus enticing to go for further investigation. In this regard, [45] finds no impact of the knowledge (education) being largely unrelated to concern, however, [46] reveals a positive link between the two. A still different viewpoint is portrayed by [47] who posits that the knowledge-concern linkage may be moderated by political ideology. Findings on age and income level too are inconsistent with some studies revealing a negative relationship between age and global warming concerns while others portray no significant or positive correlation [48-51]. Similarly, a mixed pattern of impacts and linkages are observed in the case of income and concern level [49,52].

However, this study hypothesizes a positive linkage of income with the climate change concern in the study area. In a similar vein, access to credit is supposed to positively influence people/farmers' concern as does the access to information. However, wide and contrasting findings are reported on their influence on people's concerns for climate change. Keeping in mind the above empirical account, we construct two multivariate models in the present study to test the hypothesized relationships between the unobserved discrete response variables and the observed variables. Our approach (in model 1) links the observed responses on socio-economic attributes (age, education, and income), perceived changes in climatic parameters (perceived changes in rainfall and temperature), farmers beliefs regarding climate change (climate change is due to human and nature) and their access to credit and information sources to unobserved ordinal variables and climate change concerns, through an ordered logit model.

The dominant concerns selected for the present study were identified from a list of potential sources of climate change concerns through a cumulative frequency method. The three dominant sources of climate change concerns identified through the cumulative frequency method based on their higher cumulative frequency scores are 'increased insect pressure', 'higher incidence of crop diseases', and 'droughts'. These sources of climate change concerns were then treated as dependent variables in the ordered logit model and the potential impacts of the observed variables were estimated. For model 2, we used a list of capacity-building needs of the farmers to cope with the adverse impacts of climate change and identified three major capacity building needs (Employment of ICT tools for improving the delivery of extension services, capacity building of the extension personnel and building a link between smallholder farmers and agricultural research bodies) through the cumulative frequency method. As the variables associated with the capacity building needs of the sampled respondents were dichotomous in nature, a logit model was used to estimate the impacts of climate change concerns on the capacity-building needs of the farmers as shown in Figure 1. 


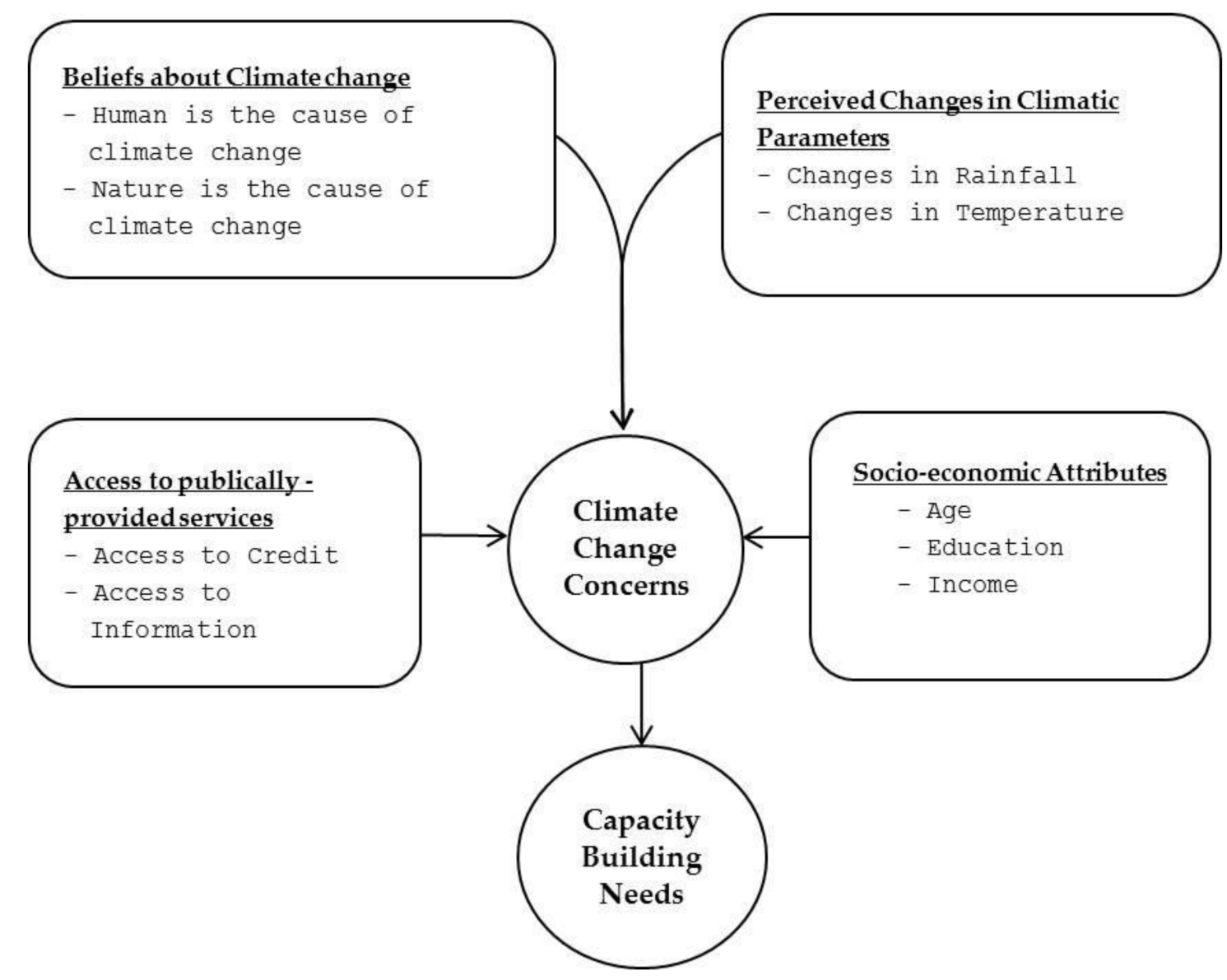

Figure 1. Conceptual model of the study.

\section{Methodology}

\subsection{Description of the Study Area}

Jazan Province is located in the southwest of Saudi Arabia and it is second smallest province of the country. The area of the province is approximately around $11,671 \mathrm{~km}^{2}$ and covers $300 \mathrm{~km}$ of the Southern Red Sea coast Figure 2. Administratively, the province consists of 16 governorates: Al-Harth, Ahad-Al-Musrarihah, Haroob, Al-Daer, Savya, AlIdabi, Faifa, Damad, Al-Aridah, Abu Arish, Jazan, Al-Darb, Al-Reath, Beash, Samttah, and Al-Twal. The region is characterized by fertile loamy soil. Despite the smallest province of Saudi Arabia in terms of geographical area (Jazan Province represents only $0.7 \%$ of the total area of the country), it is one of the richest agricultural province and hosts approximately $8 \%$ of Saudi Arabia's total farms [37]. The majority of farmers in the region are characterized as being smallholder farmers with farm size averaging between 1-3 ha. The majority of farmers cultivate vegetables, fruits, and other field crops such as maize, okra, sesame, tomatoes and millet. Annually, rainfall in the province varies from year to year ranging from $55-150 \mathrm{~mm}$; the majority of the rainfall is generally observed between January and October. The temperature ranges from 31 to 35 and 25 to $28^{\circ} \mathrm{C}$ in the summers and winters, respectively [53]. Groundwater, flash floods and rains are the main sources of irrigation water. In the recent years, drip irrigation has been adopted by farmers using rainwater harvesting techniques [37]. 


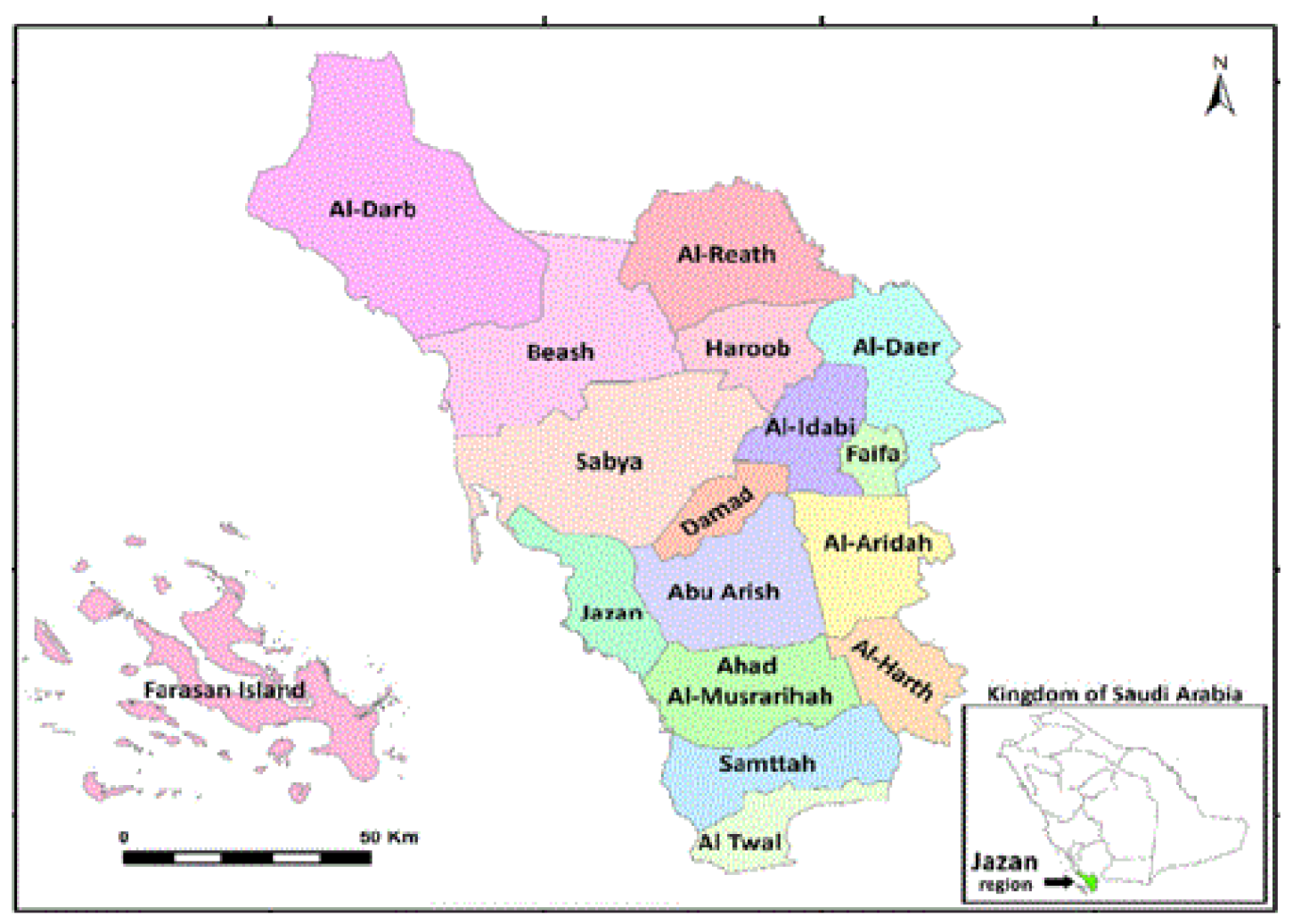

Figure 2. Map of the study area. Source: Alotaibi et al., 2020 [37].

\subsection{Research Design and Methodological Framework}

The present research is aimed at investigating the potential role of socio-economic attributes of the sampled respondents in their concerns for climate change along with perceived changes in climatic parameters, perceived causes of climate change, and access to credit and information services which ultimately translate into their capacity building needs. The study used cross-sectional data collected from randomly selected 164 farmers through a well-structured and pre-tested questionnaire. The questionnaire covered a wide range of information including the socio-economic and demographic attributes of the respondents, their perceptions regarding climate change, their beliefs and concerns, as well as their access to publicly provided services including information and credit facilities. An ordered logit model was then employed to assess the potential impacts of various factors on farmers' concerns while three individual logit models were used to determine the impacts of these concerns on the capacity-building needs of the sampled respondents for facilitating easy and faster adaptation. The findings obtained from the model were used to draw conclusions. A depiction of the methodological framework is provided in Figure 3. 


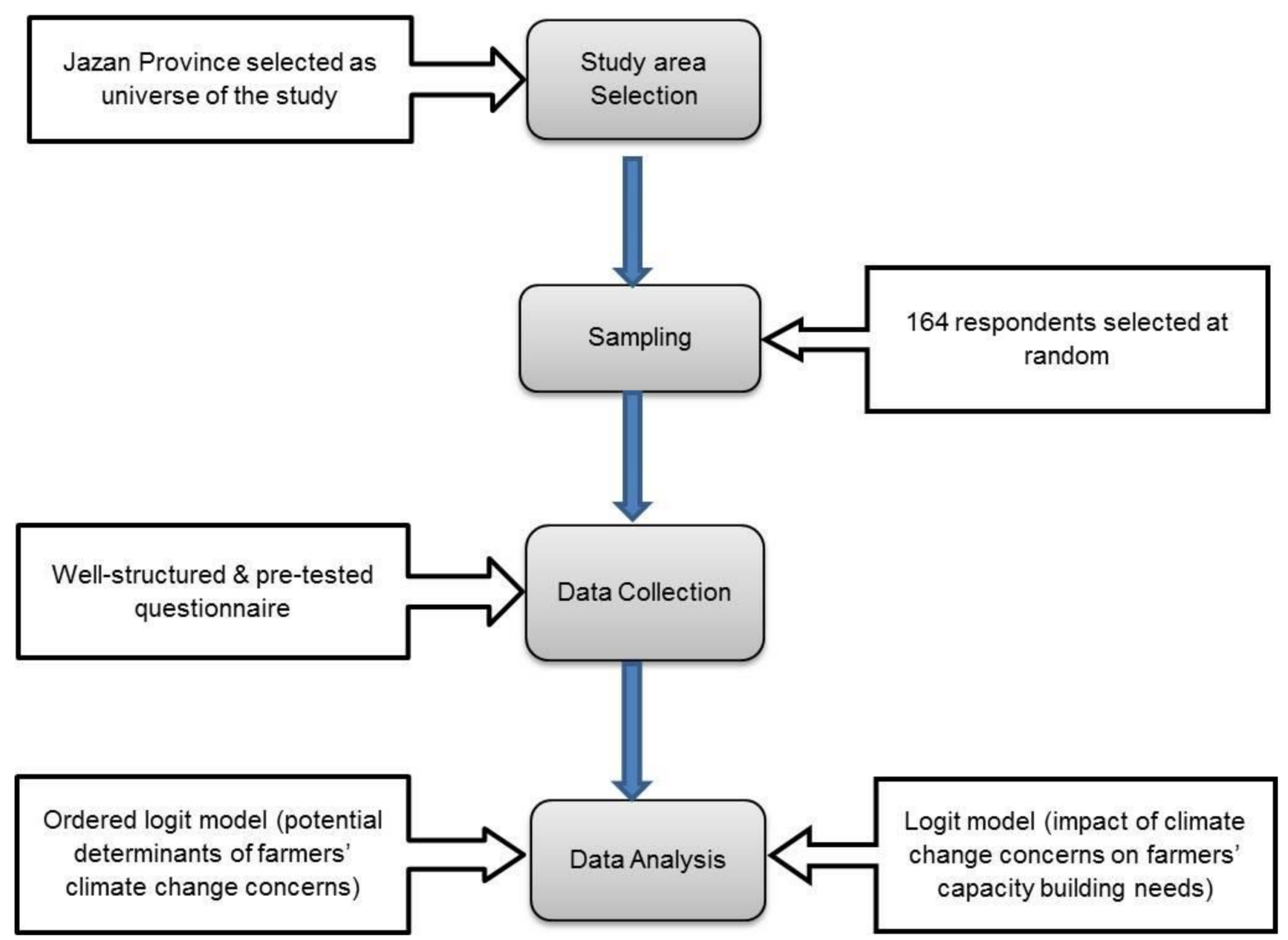

Figure 3. Methodological Framework.

\subsection{Data Collection}

The face-to-face survey technique was used to collect data from the farmers. The survey was developed and validated by a group of experts at King Saud University including extension agents in the area of study. The data were collected by in-person interviews on their farms as well as meeting some farmers at extension centers in Abu Arish. Two hundred farmers were invited to participate in the study; 164 provided full information thus resulting an $82 \%$ response rate. Before data collection from the farmers, the purpose of the research project was explained to all the farmers with the assurance of data protection and sole use for research purpose.

\subsection{Instrument}

The questionnaire covered a wide range of issues related to climate change, including farmers' background information related to socio-economic status, beliefs, concerns, capacity-building initiatives, and perceived changes in temperature and rainfall patterns. Beliefs and concern items were adopted and modified from [54], and the instrument for perceived changes in rainfall and temperature were adopted from [55]. 


\subsection{Data Analysis}

\subsubsection{Cumulative Frequency}

To identify the relative importance of sources of concerns, the following formula has been employed. The cumulative score for each source of concern was calculated and the sources were ranked based on the cumulative score:

$$
\mathrm{CS}=\mathrm{C}_{1} \times f_{1}+\mathrm{C}_{2} \times f_{2}+\mathrm{C}_{3} \times f_{3}+\mathrm{C}_{4} \times f_{4}+\mathrm{C}_{5} \times f_{5}
$$

$\mathrm{CS}=$ Cumulative Score

$\mathrm{C}_{1-5}=$ Categories

$f_{1-5}=$ Frequency in respective category

Three dominant sources of concerns were selected from the list based on the cumulative score calculated with the help of Equation (1). These scores were treated as dependent variables in the study later on.

\subsubsection{Ordered Logit Model}

Ordered logit model, also known as the proportional odds model, is an estimation technique where there is an observed ordinal variable, $Y$. There is also an unmeasured latent variable $\mathrm{y}^{*}$ with various cut points. The general form of the ordered logit model is provided as follows:

$$
Y=\beta_{0}+\beta i X i+e i
$$

where

$\mathrm{Y}=$ Concerns related to climate change (not concerned, slightly concerned, concerned, very concerned)

$\beta_{0}=$ Constant

$\beta_{\mathrm{i}}=$ Parameters to be estimated

$\mathrm{X}_{\mathrm{i}}=$ Observed variables (Socioeconomic factors, perceived causes of climate change, perceived impacts of climate change and access to credit)

ei $=$ Error Term

There are four categories of responses used for the observed ordinal variables in our study: $1=$ not concerned, $2=$ slightly concerned, $3=$ concerned, and $4=$ very concerned with three cut points in each of the equation. The categorical variable $Y$ has various threshold points; the value for the observed variable Y depends on whether one has crossed a threshold. In the present study, since there are four categories of responses (not concerned, slightly concerned, concerned, and very concerned), there are yields three cut points. The probability of an individual to fall into one of the four categories is subjected to the following conditions:

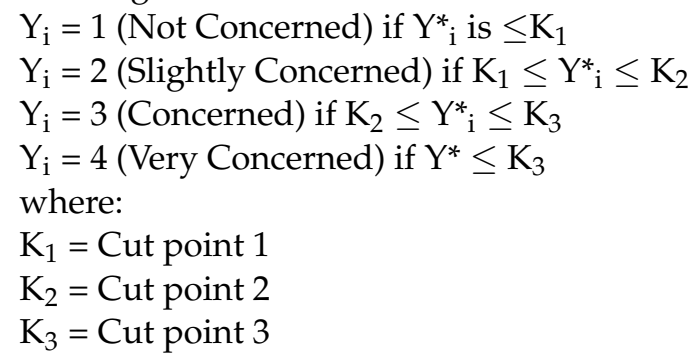

The probability of each respondent for the four categories has been calculated using the following equations:

$$
\begin{gathered}
\mathrm{P}(\mathrm{Y}=1)=\frac{1}{1+\exp (Z i-K 1)} \\
\mathrm{P}(\mathrm{Y}=2)=\frac{1}{1+\exp (\mathrm{Zi}-\mathrm{K} 2)}-\frac{1}{1+\exp (\mathrm{Zi}-\mathrm{K} 1)} \\
\mathrm{P}(\mathrm{Y}=3)=\frac{1}{1+\exp (\mathrm{Zi}-\mathrm{K} 3)}-\frac{1}{1+\exp (\mathrm{Z} i-\mathrm{K} 2)}
\end{gathered}
$$




$$
\mathrm{P}(\mathrm{Y}=4)=1-\frac{1}{1+\exp (Z i-K 3)}
$$

The ordered logit model was estimated separately for the three dominant sources of concerns faced by the agricultural producers in the study area, which were 'increased insect and pest infestation increased frequency of diseases', and 'increase in frequency and severity of droughts. The estimation procedure used for estimating the impacts of climate change concerns on farmers' needs for capacity-building initiatives to mitigate the adverse impacts of climate change was accomplished through logit regression as the dependent variable takes a binary form.

\section{Results}

This section provides the findings in light of the main objectives of the study as indicated in the introduction. Findings focus ranking of concerns and beliefs of the respondents about climate change along with the perceived capacity-building initiatives to equip community for effective climate change mitigation and adaptation. The potential role of various factors in shaping the concerns of the individuals about climate change along with the role of similar factors in shaping the need/importance of perceived capacity-building initiatives are also noted for a clearer understanding of the adaptation dynamics to facilitate policy planning using ordered logit models. The first sub-section provides the ranking of concerns, beliefs, and perceived/implemented strategies, while the second sub-section gives summary statistics of variables used in the study, while the third sub-section highlights the role of these factors in shaping the concerns of the sampled respondents, and the last sub-section presents impacts of climate change concerns over farmers' capacity building needs.

\subsection{Ranking of Climate Change Concerns, Beliefs and Capacity-Building Initiatives}

There were a number of climate change concerns identified from the previous studies and the respondents were asked to rank each of the climate change concern on a five-point likert scale from 1 (very low) to 5 (very high). The cumulative frequency score (Equation (1)) was then used to rank the sources of climate change concerns (Table 1).

Table 1. Ranking of farmers' concerns about climate change impacts.

\begin{tabular}{ccc}
\hline Concerns & Cumulative Score & Ranking \\
\hline Increased drought & 467 & III \\
Increased flooding & 461 & VI \\
Increased appearance of weeds & 464 & IV \\
Increased insect pressure & 489 & $I$ \\
Higher incidence of crop diseases & 473 & II \\
Increased soil erosion & 443 & VIII \\
Increased heat stress on crops & 463 & V \\
Increased saturated soils and ponded water & 452 & VII \\
\hline
\end{tabular}

There were a number of perceived capacity-building initiatives for climate change mitigation identified during the surveys, however, the present study considered the three dominant capacity-building measures for further analysis, namely 'employment of ICT tools for improving the delivery of extension services and products', 'capacity-building of the extension personnel', and 'building a viable link between smallholder farmers and agricultural research bodies'.

Similar to the ranking of concerns about climate change, ranking of responses was conducted regarding the farmers' beliefs about climate change as well as requisite strategies for capacity-building in order to avoid/mitigate harmful effects of climate change within the study area. These rankings, estimated using Equation (1), are presented in Tables 2 and 3, respectively. This is necessary for placing policy guidelines in perspective and to align them with farmers' perceptions about possible impacts as well as the potential 
adaptation options. Many researchers have noted the need for aligning policy interventions such that people are mentally-prepared and think the interventions are effective within a given scenario [56-60]. These studies point towards the introduction of initiatives that people perceive to be effective in terms of their efficacy and control. When done so within the proper context, the uptake of these strategies becomes relatively faster as ultimate beneficiaries are assured of the effectiveness and applicability.

Table 2. Ranking of beliefs towards climate change among survey respondents of the study area.

\begin{tabular}{ccc}
\hline Beliefs & Cumulative Score & Ranking \\
\hline Anthropogenic activities are causing climate change. & 690 & II \\
Nature is causing climate change. & 693 & I \\
Lack of concrete evidence that climate change is happening. & 454 & IV \\
Both nature and anthropogenic activities are behind & 635 & III \\
climate change. & 320 & V \\
\hline
\end{tabular}

Table 3. Ranking of capacity building initiatives necessary for effective climate change adaptation in the region.

\begin{tabular}{ccc}
\hline Strategy/Initiative & Cumulative Score & Ranking \\
\hline Awareness meetings with the farming community. & 647 & IX \\
Field days for showing technology related to climate & 668 & V \\
change adaptation. & 661 & VIII \\
On-farm demonstrations for enhancing farmers' skills. & 677 & IV \\
Farmer-to-farmer extension approach. & 665 & VI \\
Farmers' training on post-harvest food management. & 664 & VII \\
Weather forecast alerts. & 639 & X \\
Use of farmer field school extension approaches for & 687 & III \\
developing farmers' problem-solving skills. & 692 & II \\
Building a viable link between smallholder farmers and & 694 & I \\
agricultural research bodies. & 694 Capacity building of the extension personnel. & \\
Employment of ICT tools for improving the delivery of & extension services and products. &
\end{tabular}

As given in Table 2, many farmers in the study area believe that climate change is a form of natural change. This is evident from the rankings of statements about climate change beliefs by the respondent farmers. At the first and second place are natural changes and anthropogenic activities that cause climate changes, respectively. At the third place, the cause of climate change is reported to be the combined effect of human and natural causes. The fourth and fifth rankings show a sort of skepticism among respondents who believe that either they do not have sufficient evidence to comment on the nature of climate change or there is no climate change, with cumulative scores of 454 and 320, respectively, using Equation (1).

In the similar fashion and calculated with the same equation, the capacity-building initiatives deemed useful and felt necessary by the respondents for effective climate change adaptation are listed with their respective scores in Table 3. The top three strategies obtained are: 'use of information and communication technologies (ICTs) in disseminating information and awareness creation about climate change impacts and adaptation measures'; 'capacity building and theme-specific training of the extension staff related to climate change for promoting adaptation interventions'; and 'linking smallholder farmers with agricultural research for on-farm adaptive mechanisms for climate change under various types of farming systems. The other least-popular or least-effective strategies perceived and reported by the respondents are 'the use of farmers' fields schools for training farmers (tenth rank)', 'conducting awareness meetings with farmers (ninth rank)', and 'conducting 
demonstrations for providing innovations on climate change adaptation (eighth rank)'. These findings do imply that the traditional methods of agricultural extension are not perceived as effective thus necessitating a paradigm shift in agricultural information transmission mechanism. Farmers do not perceive traditional ways of awareness creation at the micro level to be effective or give them low preference, such as awareness meetings, demonstration events, or farmers' field schools.

\subsection{Summary Statistics of Variables Used in the Study}

Table 4 indicates that the majority of the sampled respondents (44.5\%) were concerned regarding increased insect infestation due to climate change, followed by $29.3 \%$ farmers who were very concerned regarding increased insect infestations. For increased frequency of diseases, the majority ( $53 \%$ ) of the sampled respondents were concerned, while $29.9 \%$ were very concerned. Similarly, 71 sampled respondents reported concern over droughts while 54 sampled respondents were slightly concerned about this issue. A general observation of the table shows that most of the respondents were either concerned or very concerned about the three-mentioned sources of climate change impacts.

Table 4. Frequency distribution of discrete variables of the model.

\begin{tabular}{|c|c|c|c|}
\hline Variables & Categories & Frequency & Percentage \\
\hline \multirow{4}{*}{ Increased Insects infestation } & Not concerned & 4 & 2.4 \\
\hline & Slightly Concerned & 39 & 23.8 \\
\hline & Concerned & 73 & 44.5 \\
\hline & Very concerned & 48 & 29.3 \\
\hline \multirow{4}{*}{ Increased Frequency of Diseases } & Not concerned & 5 & 3.0 \\
\hline & Slightly Concerned & 23 & 14.0 \\
\hline & Concerned & 87 & 53.0 \\
\hline & Very concerned & 49 & 29.9 \\
\hline \multirow{4}{*}{ Droughts } & Not concerned & 2 & 1.2 \\
\hline & Slightly Concerned & 54 & 32.9 \\
\hline & Concerned & 71 & 43.3 \\
\hline & Very concerned & 37 & 22.6 \\
\hline \multirow{4}{*}{ Education } & Less than high school & 82 & 50.0 \\
\hline & High school & 29 & 17.7 \\
\hline & Bachelor & 25 & 15.2 \\
\hline & Graduate School & 28 & 17.1 \\
\hline \multirow{2}{*}{ Perceived Changes in Rainfall Patterns } & Yes & 128 & 78 \\
\hline & No & 36 & 22 \\
\hline \multirow{2}{*}{ Perceived Changes in Temperature } & Yes & 140 & 85.4 \\
\hline & No & 24 & 14.6 \\
\hline \multirow{5}{*}{ Human as a cause of climate change } & Strongly Disagree & 6 & 3.7 \\
\hline & Disagree & 1 & 0.6 \\
\hline & Neutral & 10 & 6.1 \\
\hline & Agree & 78 & 47.9 \\
\hline & Strongly Agree & 69 & 42.3 \\
\hline \multirow{5}{*}{ Nature as a cause of climate change } & Strongly Disagree & 5 & 3.1 \\
\hline & Disagree & 2 & 1.2 \\
\hline & Neutral & 5 & 3.1 \\
\hline & Agree & 88 & 54 \\
\hline & Strongly Agree & 64 & 39.3 \\
\hline \multirow{2}{*}{ Access to Credit } & Access & 23 & 14.1 \\
\hline & No access & 141 & 85.9 \\
\hline
\end{tabular}

Half of the sampled farmers were found to have less than a high school education $(50 \%)$ followed by farmers with a high school diploma $(17.7 \%)$ indicating that the sampled 
farmers have lower educational attainments in the study area. During the surveys, farmers were asked to report the potential impacts of climate change. The majority of the farmers reported that changes in rainfall patterns and changes in temperature are the major impacts of climate change observed by them in the recent years. The majority of the respondents either agreed $(47.9 \%)$ or strongly agreed $(42.3 \%)$ with the statement that human activities are the main cause of climate change. Similarly, most of the sampled farmers (54\%) agreed with the statement that nature itself is a cause of climate change followed by $39.3 \%$ respondents who strongly agreed with the same statement. This reflects that the sampled farmers consider both human activities and nature to be the potential causes of climate change. Among the sampled farmers surveyed for the study, only 23 sampled farmers have access to credit facilities while 141 farmers reported to have no access to credit facilities. The frequencies of the categorical/discrete variables are provided in the Table 4 along with their percentages.

Table 5 presents the averages and standard deviations of the variables included in the ordered logit and binary logit models. As evident from Table 5, the average age reported in the study area was 47 years with a standard deviation of 9.47 , while the average yearly income was found to be 7894.71 SAR with a standard deviation of 9064.89. The high standard deviation in the income of the sampled respondents reflects a high degree of variation in incomes of the farmers. The average number of contacts by the farmers with extension workers for information related to climate change was found to be 4.43 with a standard deviation of 1.79 .

Table 5. Descriptive statistics of variables.

\begin{tabular}{ccc}
\hline Variable (Unit) & Mean & Standard Deviation \\
\hline Age (years) & 47.10 & 9.47 \\
Income (SAR (SAR is abbreviation for Saudi Riyal, & 7894.71 & 9064.89 \\
I SAR = 0.27 USD (Approx.))/year) from farming & 4.43 & 1.79 \\
\hline
\end{tabular}

\subsection{Factors Affecting Concerns of the Farmers}

The findings of the empirically estimated ordered logit model are provided in Table 6. The findings highlight the importance of various factors affecting the top concerns (insect infestation, disease prevalence, and droughts) of farmers regarding climate change. This study reveals some interesting points related to the covariates of pro-environmental behavior (concerns about climate change) taking into account socioeconomic, anthropogenic, and environmental aspects either stated or observed.

\subsubsection{Socioeconomic Attributes}

Among the socioeconomic attributes of the farmers, age positively affects the concerns of the sampled farmers regarding droughts. The relationship is positive and significant at the 5 percent probability level and the odds-ratio indicates that a one unit (one year) increase in the age raises concerns of farmers for droughts by 1.042 times $(4.2 \%)$. The nature of the impact of this variable as well as the positive sign are in line with our a priori expectations. However, age is negatively but non-significantly related with concern for insect infestations and the increased frequency of diseases in the study area.

Findings on education vis-à-vis the perceived probability of increased concern for insect infestation are somewhat surprising yet justifiable. Education has an inverse and significant relationship with concern for increased insect infestation. The odds-ratio suggest that an increase in education of farmer from lower category of education to higher category will decrease the concerns of farmers for increased insect infestation due to climate change by 0.730 times $(27 \%)$.

As far as the insects are concerned, a variety of insect pests cause serious damage to a range of crops and vegetables in the south of Saudi Arabia including the Alfalfa weevil, aphids, and thrips, which are the main pests of the Alfalfa crop. The Red Palm Weevil and 
scale insects are common to the date palm. Fruit flies are common to all fruits grown in the region. Spider mites cause severe damage to cucumbers. Moreover, cucumber is also attacked by thrips, whitefly, and aphids. Okra is mainly attacked by borers, whitefly, and mealybugs. Tuta absoluta (tomato leaf miner) is the most common pest of tomato. Bringle is generally infested by borers, thrips, and spider mites. Citrus leaf miner, fruit flies, and scale insects are common to citrus crop.

Regarding the role of income, farmers' income plays a critical role in shaping their concerns regarding climate change impacts. The findings show that higher income of the farmers significantly reduces their concerns about increased insect infestation and increased frequency of diseases, while it significantly increases concerns of droughts. These findings are intuitive too with varying implications. With higher incomes, farmers can use various tools for ex ante mitigation and ex post coping with the insect infestation and diseases. However, their incomes cannot, in general, help in easing their concerns of droughts, the effect of which are generally beyond their control. Such a relationship between farmers' income and pro-environmental behavior is reported by [44,57].

Table 6. Parameter estimates of the Ordered Logit Model.

\begin{tabular}{|c|c|c|c|c|c|c|}
\hline \multirow{2}{*}{ Variables } & \multicolumn{2}{|c|}{ Increased Insects Infestation } & \multicolumn{2}{|c|}{$\begin{array}{l}\text { Increased Frequency } \\
\text { of Diseases }\end{array}$} & \multicolumn{2}{|c|}{ Droughts } \\
\hline & Co-Efficient & Odds-Ratio & Co-Efficient & Odds-Ratio & Co-Efficient & Odds-Ratio \\
\hline \multicolumn{7}{|c|}{ Socioeconomic Attributes } \\
\hline Age & $-0.01(0.01)$ & 0.98 & $-0.020(0.01)$ & 0.97 & $0.041^{* *}(0.01)$ & 1.04 \\
\hline Education & $-0.31 * *(0.15)$ & 0.73 & $0.18(0.15)$ & 1.19 & $0.235(0.15)$ & 1.26 \\
\hline Income & $\begin{array}{c}-0.00005^{* *} \\
(0.00002)\end{array}$ & 0.99 & $\begin{array}{l}-0.00003 * \\
(0.00002)\end{array}$ & 0.99 & $\begin{array}{l}0.00004^{* *} \\
(0.00001)\end{array}$ & 0.99 \\
\hline \multicolumn{7}{|c|}{ Perceived Changes in Climatic Parameters } \\
\hline Changes in Rainfall Patterns & $1.72 * * *(0.47)$ & 1.77 & $0.904^{* *}(0.45)$ & 1.40 & $0.021(0.44)$ & 1.01 \\
\hline Changes in Temperature & $0.73(0.68)$ & 2.08 & $1.306 *(0.73)$ & 3.69 & $1.675^{* *}(0.68)$ & 5.33 \\
\hline \multicolumn{7}{|c|}{ Perceived Causes of Climate Change } \\
\hline Human & $0.53 * *(0.24)$ & 1.71 & $0.679^{* * *}(0.26)$ & 1.97 & $0.249(0.23)$ & 1.28 \\
\hline Nature & $0.14(0.25)$ & 1.15 & $0.30(0.26)$ & 1.35 & $-0.136(0.24)$ & 0.87 \\
\hline \multicolumn{7}{|c|}{ Access to Credit and Information } \\
\hline Credit Access & $1.53^{* * *}(0.56)$ & 4.63 & $1.570^{* * *}(0.55)$ & 4.80 & $2.395^{* * *}(0.57)$ & 10.96 \\
\hline Access to information & $-0.02 *(0.01)$ & 0.87 & $\begin{array}{c}-0.038^{* *} \\
(0.01)\end{array}$ & 0.86 & $-0.11(0.17)$ & 0.94 \\
\hline Cut 1 & \multicolumn{2}{|c|}{$-4.22(1.53)$} & \multicolumn{2}{|c|}{$0.058(1.58)$} & \multicolumn{2}{|c|}{$-1.896(1.65)$} \\
\hline Cut 2 & \multicolumn{2}{|c|}{$-1.39(1.47)$} & \multicolumn{2}{|c|}{$2.470(1.57)$} & \multicolumn{2}{|c|}{$2.370(1.47)$} \\
\hline Cut 3 & \multicolumn{2}{|c|}{$1.00(1.46)$} & \multicolumn{2}{|c|}{$5.449(1.61)$} & \multicolumn{2}{|c|}{$4.697(1.51)$} \\
\hline Log likelihood & \multicolumn{2}{|c|}{-163.32} & \multicolumn{2}{|c|}{-149.18} & \multicolumn{2}{|c|}{-159.15} \\
\hline $\mathrm{LR} \mathrm{Chi}^{2}(12)$ & \multicolumn{2}{|c|}{$42.95^{* * *}(0.000)$} & \multicolumn{2}{|c|}{$47.95^{* * *}(0.000)$} & \multicolumn{2}{|c|}{$40.89^{* * *}(0.000)$} \\
\hline Pseudo $\mathrm{R}^{2}$ & \multicolumn{2}{|c|}{0.11} & \multicolumn{2}{|c|}{0.13} & \multicolumn{2}{|c|}{0.11} \\
\hline
\end{tabular}

Note: Figures in parenthesis are standard errors. ${ }^{*}{ }^{* *}$, and ${ }^{* * *}$ represent significance at $10 \%, 5 \%$ and $1 \%$ probability levels, respectively.

\subsubsection{Changes of Climatic Parameters}

The perceived changes in the climatic parameters particularly changes in rainfall patterns have a significant impact on the concerns of farmers particularly related to insect infestation and disease frequency. In particular, perceived changes in rainfall patterns significantly affect farmers' concerns regarding increased insect infestation and increased frequency of diseases. Farmers with higher perceived changes in rainfall patterns have more concerns over incidence of insect infestation $(77.8 \%$ higher concern as compared to farmers with lower perceived changes in rainfall patterns) and diseases (40.5\% higher concerns over farmers with lower perceived changes in rainfall patterns). For perceived changes in temperature, the concerns for increased frequency of diseases and droughts are significantly higher. Farmers with higher levels of perceived changes in temperature tend to have higher concerns for increased frequency of diseases (3.69 times higher concerns compared to farmers with lower levels of perceived changes in temperature) and droughts 
(5.339 times higher concerns compared to farmers with lower levels of perceived changes in temperature). In addition, higher levels of perceived changes in rainfall do not show a significant impact on the level of concern linked with drought. Similarly, higher levels of perceived changes in temperature show a non-significant but positive association with increased insect infestation.

\subsubsection{Perceived Causes of Climate Change}

The findings reflect that among the perceived causes of climate change, human causes are reported to be significant in increasing farmers' concerns for higher rates of insect infestation and plant diseases. Farmers perceiving humans as the cause of climate change are more concerned for increased insect infestation (1.71 times more than farmers perceiving humans as not being the cause of climate change). Similarly, farmers who perceive humans as a cause of climate change have 1.97 times higher concerns over increased frequency of diseases compared with farmers perceiving otherwise. The perception of farmers about nature being primary cause of climate change is found to be less prominent and nonsignificant as well as the cause of concerns related to the top three concern categories.

\subsubsection{Access to Farm Credit and Information}

For the variable on access to farm credit, the results are surprising despite having theoretical validity. The credit beneficiaries were expected a priori to be more-secure and thus less concerned because of the availability of financial support for installing climatemitigation facilities, tools, and infrastructure. However, our findings suggest that farmers with access to credit facilities have more concerns for all three types of selected (major) concern sources. This result implies that increased use of and/or access to farm credit by the farmers would increase their concerns for insect infestation, disease severity, and drought amidst climate change. The finding is intuitive, however, and should be subject to academic and empirical investigation in future research. Nevertheless, we posit it as one of the policy factors indirectly influencing farmers' attitude towards risk. There is economic reasoning that could explain this outcome as well because firms (here farmers) relying on external funds would be more cautious and vigilant towards any risk of external shock(s) threatening the sustainability of their enterprise as well as their repaying capacity.

The findings of the estimated ordered logit model revealed that farmers with access to credit facilities have 4638,4808, and 10,968 times greater concerns for increased insect infestation, increased frequency of crop diseases, and droughts, respectively, compared to farmers with no access to credit facilities.

As evident from the results, an increased frequency of contacts with extension workers for climate-related information significantly reduces farmers' concerns for increased insect infestation and increased frequency of diseases. Based on the odds-ratios, an additional contact with extension workers for information on climate change reduces the concerns of the farmers for increased insects' infestation 0.878 times $(12.2 \%)$, while it reduces the concerns of farmers for increased frequency of diseases 0.862 times $(13.8 \%)$.

However, the parameter on access to information in case of droughts is expected a proiri to have a negative sign though being non-significant.

\subsection{Impacts of Climate Change Concerns on Farmers Capacity-Building Needs}

The impact of climate change concerns on respondents' needs for capacity-building initiatives are estimated using ordered logit model and the findings are provided in the following table.

As evident from Table 7, the climate change concerns have positive impact on the farmers' needs for capacity-building initiatives. The findings highlight the importance of studying the climate change concerns of the agricultural producers as these concerns increase their desire for the required capacity-building initiatives. Concerns regarding increased pest pressure, for example, positively influences farmers' needs for capacity building through the use of ICT tools that can improve service delivery of extension 
services, capacity building of the extension personnel, and establish viable links between smallholders and agricultural research centers.

Table 7. Impacts of Climate change concerns on Farmers' capacity building needs.

\begin{tabular}{cccc}
\hline Variables & $\begin{array}{c}\text { Employment of ICT Tools } \\
\text { for Improving the Delivery } \\
\text { of Extension Services }\end{array}$ & $\begin{array}{c}\text { Capacity Building of the } \\
\text { Extension Personnel }\end{array}$ & $\begin{array}{c}\text { Building a Link between } \\
\text { Smallholder Farmers and } \\
\text { Agricultural Research Bodies }\end{array}$ \\
\hline $\begin{array}{c}\text { Increased pest pressure } \\
\text { Increased diseases infestation }\end{array}$ & $0.177(0.235)$ & $0.310(0.232)$ & $0.217(0.237)$ \\
Droughts & $0.310(0.235)$ & $0.122(0.231)$ & $0.350(0.247)$ \\
Cut1 & $0.335(0.210)$ & $0.579 * * *(0.211)$ & $0.666^{* * *}(0.209)$ \\
Cut2 & $-2.090(1.008)$ & $-1.213(0.888)$ & $-1.769(1.216)$ \\
Cut3 & $0.060(0.787)$ & $0.773(0.748)$ & $1.518(0.780)$ \\
Cut4 & $1.031(0.785)$ & $2.151(0.767)$ & $2.810(0.801)$ \\
Log likelihood & $3.049(0.818)$ & $4.012(0.810)$ & $4.713(0.852)$ \\
LR Chi ${ }^{2}(3)$ & -196.099 & -209.859 & -203.831 \\
Pseudo R & $10.42 * *$ & $17.23 * * *$ & $23.79 * * *$ \\
\hline
\end{tabular}

Note: Figures in parenthesis are standard errors. ${ }^{* *}$ and ${ }^{* * *}$ represents significance at $5 \%$ and $1 \%$, respectively.

Similarly, findings are noted for concerns regarding increased disease infestation due to climate change and the resultant positive impacts on farmers' needs of the increased and improved capacity-building programs. Most notable are the impacts of concerns regarding drought on farmers' needs of capacity-building initiatives particularly, capacity-building of extension personnel, and establishing viable links between smallholders and research bodies where the impacts are positive and statistically significant at $1 \%$ probability levels.

\section{Discussion}

Many of the findings of the present study are intuitive and find a valid place in literature as well as reality of the study area. Concerning the capacity-building strategies, farmers perceived the most effective and desired strategies to be institution-led awareness campaigns through ICTs, personnel training and on-farm adaptive training related to climate change. All these strategies have been reported to be highly effective in the case of studied country as well as other countries in the world [61]. Similarly, [62] highlights the need for capacity-building through short-term training and long-term education customized to local situation as being the most effective tools for climate change adaptation. However, the finding on creating awareness at local level through demonstration events and farmers' field schools contradicts with $[63,64]$ who report a healthy role of these two interventions in sensitizing community for adaptation actions.

Evaluating awareness about the consequences of a particular change provides evidence of pro-environmental and altruistic attitudes along with some degree of perceived personal responsibility, which could lead to effective adoption or at least willingness to adopt avoidance-mechanisms and strategies [65,66]. Having an idea about the level of understanding on the climate change is seen to be instrumental for building capacity as well as planning an effective mitigation strategy [39-43]. As reported by [45], the coping capacity as well as personal characteristics of individual shape adaptation drive along with supporting a broader policy agenda towards climate change mitigation. These findings do support results of this work about the role of awareness and education for effective mitigation planning and resilience-building. In a similar fashion, the observation on farmers' age and its role in shaping the concerns is justified by many researchers who posit that increase in the age of a person would lead to enhanced awareness and concern about environmental dynamics because of his/her life experiences over time [67-71]. Nevertheless, literature also exists showing the contrasting nature of impact by this variable as having a negative impact on environment-related awareness/concerns [72-74]. Thus, our results and previ- 
ous empirical findings do provide insights into the role of age of a particular individual in realizing a pertinent issue associated with unwanted consequences, particularly drought.

The findings on the role of education vis-à-vis climate change concern imply that with increased levels of education, farmers will be more-prepared and confident to monitor, to pest-scout, and to curb insect outbreaks, thus leading to effective control. In other words, farmers are not highly concerned about insects when they have more knowledgevia higher educational attainment-about how to monitor and counter insect infestation. This argument is justified on two grounds: more education helps farmers to locate any insect population in a timely manner and then taking viable and pest-specific control measures based on their information inventory either in the form of field-level knowledge, technical know-how, effective use of ICTs in agriculture, or access to field staff from pest control departments and organizations $[75,76]$. Such outcomes for education have been evidenced by [77-79]. The second aspect of this finding points towards the increased ability of educated farmers to diagnose insect attacks and subsequently and speedily plan remedial action(s)/measures instead of panicking or developing concerns ultimately failing to devise an effective mitigation strategy thereof. As pointed out by $[44,80,81]$, if people understand that there is climate change taking place courtesy of humans with potential negative consequences, they would be theoretically concerned about it, however, such an understanding is generally rooted in influential misperceptions.

Household incomes is often misinterpreted when linking it with disaster-mitigation drive. It is generally believed that higher income may instill a sense of perceived control with a view of being less-vulnerable towards any stimulus, yet its impact on risk perception/concern level appears marginal [49-51]. Nevertheless, the finding on household incomes provides intuitive justifications under a particular regional or geopolitical context [44]. There is a huge body of evidence, though, which shows that increased income of households may make them well-prepared to control any insect or disease outbreaks as they can use their income to achieve timely application of pesticides and chemicals instead of developing concerns when faced with income constraint [82,83]. However, as drought is beyond human control to a large extent, farmers with relatively higher incomes will be more concerned about droughts compared with those having lower incomes. This is understandable because the high-income farmers may have relatively large cropped areas at risk of destruction due to droughts leading to a larger quantity of expected loss as noted by [84]. Such a perception of higher farm losses in the wake of incessant droughts or any other stimulus may increase their concerns $[83,85,86]$. The ultimate mitigation options towards drought might include some limited options adopted at the farm-level such as sowing of drought-resistant varieties, water conservation through the construction of mini dams, among other techniques [87-89]. The findings related to the impact of increased rainfall in perceiving higher level of concern for insect infestation as well as disease attack among farmers of the study area are equally justified on the basis of previous research findings related to the perception of climate change impacts [90-92]. One can intuitively decipher that increased moisture content and humidity would lead to higher level of insect infestation as well as incidence and severity of diseases [93-95] leading to increased concern level among farmers [96]. Likewise, a decline in rainfall will reduce the number of insects as well as disease severity by reducing moisture content in the air, thus putting a downward pressure on farmers' concerns about insects related to climate change [97]. Regarding perceived changes in temperature, an upward shift in temperature exerts a significantly positive effect on farmers' concerns related to climate change in the form of increased concern about disease severity and droughts. Increasing temperatures will evidently increase evaporation of water sources along with scarce rainfall, and therefore could lead to higher incidence and severity of droughts [90-92]. However, increased temperatures having positive influence on disease severity can be subjected to further research.

Considering the role of farm finance on climate change concern levels, farmers relying on or using farm finance would be much more concerned if they perceive any abrupt change(s) in climate-related phenomena [55]. Therefore, one can argue for the mediating 
role of credit availability and utilization in the farm business in promoting climate vigilance through increased concern levels [89]. One of the research implications of this finding is the need to test the role of farm credit in promoting pro-environmental behavior and/or perceived impacts of climate change among credit beneficiaries. On the other hand, policy implication of this finding lies in the linking of farm-credit with climate change adaptation packages. In addition to all the reported variables and their impact on concern level, the role of information and awareness is the most pressing variable with a highly intuitive impact on sensitizing rural communities about the vagaries of weather and their impacts thereof. Earlier findings, too, show that access to information has greatly affected the concerns of farmers about climate change globally as well as in the studied country's region [98-103]. In the similar manner, people's perceived capacity-building initiatives under given perspective of climate change concerns are reported to be significantly related with a particular set of climate change stimulus, such as droughts for which capacity building of extension staff as well as developing viable linkages between small farmers and research bodies are deemed effective [62-64,104].

\section{Conclusions}

The present study attempted to identify different concerns of the farming community regarding climate change impacts and explored various factors that influence these concerns. The findings reveal that the vast majority of the studied farmers believed that climate change is happening and the major causes for this phenomenon include both anthropogenic activities as well as natural processes. The majority of the farmers expressed their concerns for increased insect infestations and increased frequency of crop diseases as a consequence of climate change. Although farmers are also concerned about drought, they don't weight it as severely as insect infestations and crop diseases. The results of ordered logit models showed a significant relationship among various variables. Age and income level had a significant and positive relationship with farmers' concerns regarding drought. Farmers' education and income level had a statistically significant and negative relationship with their concerns regarding insect infestations. Income level also showed a significant negative relationship with farmer's concerns regarding increased frequency of diseases. Farmers who had access to credit facilities expressed higher level of concerns regarding all three climate change impacts. Similarly, farmers who perceived that climate change is happening due to anthropogenic activities were more concerned about increased insect infestations and increased frequency of diseases. On the other hand, farmers' access to information related to climate change significantly reduced their concerns for increased insect infestations and increased frequency of diseases. Higher perceived changes in rainfall are shown to significantly increase farmers' concerns regarding insect infestations and increased frequency of diseases whereas higher perceived changes in temperature significantly increased farmers' concerns regarding increased frequency of diseases and droughts. Apart from climate change concerns, farmers identified three major capacity-building initiatives as being effective for developing and enhancing climate change adaptation including use of ICT tools for creating awareness among farmers regarding climate change issues and relevant adaptation practices; capacity development of the extension personnel to enhance their knowledge; and linking of the smallholder farmers to agricultural research bodies for developing on-farm climate adaptation solutions.

Findings of this work have several practical and policy-level implications for effective adaptation packages with the integration of farmers' level perceived options vis-à-vis concerns for various climate change stimuli such as drought, insect infestation, and diseases. These findings support the designing of and implementation of extension programs, particularly for the smallholder farmers with low educational backgrounds for developing climate change awareness and adaptability. The study findings advocate financial support on easy terms to the marginal farmers to enable them to go for effective farm-level interventions to minimize production risk as well as protective/pro-active strategies to reduce the brunt of climate extreme events particularly droughts, diseases, and insect 
attack. This can be envisioned through the introduction of crop-loan insurance scheme with varying contribution in the premium by the government based on farmers' own mitigation/adaptation level and his/her views for future strategies. This will instill a sense of ownership among farmers if they are supported through timely and relevant information along with technical/financial incentives if the mitigation efforts originate from and/or exist at the farm. More importantly, the educational and training institutes need to provide problem-solving and evidence-based interventions as per regional/local requirements. This is possible only if the community is taken on board at the planning phase and their participation is ensured in the implementation phase afterward. Nevertheless, there needs to be an effective and timely evaluation mechanism in terms of efficacy, finance, manpower requirements, and institutional support for specific adaptation plan. Moreover, the government should also emphasize capacity-building of the extension staff in terms of their ability to understand and offer appropriate solutions related to sustainable climate change adaptation and mitigation practices. The findings also provided important insights to inform policy discourse and enrich academic discussion on climate change concerns and their associated perceived risks.

There is still a room for future research to advance our understanding of the dynamics linked with climate change concerns, beliefs, and capacity-building initiatives. One such option is the linking of farmers' perceptions on climate risk with the adopted actions for the study area. Research is further warranted to understand the impact of site- or region-specific interventions on the climate change impacts. Another avenue for future research lies in the role of farm credit in influencing climate change concerns as well as its further role in the uptake of adaptation suit/number of adaptation options.

Author Contributions: Conceptualization, B.A.A. and A.A.; Data curation, M.I.A.; Formal analysis, A.A. and R.U.; Investigation, B.A.A. and R.K.N.; Methodology, R.U.; Project administration, H.S.K.; Resources, B.A.A.; Supervision, B.A.A.; Validation, M.I.A.; Suggestions, H.S.K.; Writing-original draft, B.A.A. and A.A.; Writing-review and editing, R.K.N. All authors have read and agreed to the published version of the manuscript.

Funding: This research was funded by Researchers Supporting Project Number (RSP- 2021/403), King Saud University Riyadh, Saudi Arabia.

Institutional Review Board Statement: Not applicable.

Informed Consent Statement: Not applicable.

Data Availability Statement: The data supporting reported results can be provided upon request to the interested individuals/researchers.

Conflicts of Interest: The authors report no conflict of interest.

\section{References}

1. IPCC. Summary for Urban Policymakers: What the IPCC Special Report on Global Warming of $1.5^{\circ} \mathrm{C}$ Means for Cities; Intergovernmental Panel on Climate Change: Geneva, Switzerland, 2018.

2. WMO. WMO Statement on the State of the Global Climate in 2018; World Meteorological Organization: Geneva, Switzerland, 2019.

3. UNESCO. United Nations World Water Development Report 2020: Water and Climate Change; United Nations Educational, Scientific and Cultural Organization: Paris, France, 2020.

4. DeNicola, E.; Aburizaiza, O.S.; Siddique, A.; Khwaja, H.; Carpenter, D.O. Climate change and water scarcity: The case of Saudi Arabia. Ann. Glob. Health 2015, 81, 342-353. [CrossRef] [PubMed]

5. IPCC. Climate Change 2014: Synthesis Report. Contribution of Working Groups I, II and III to the Fifth Assessment Report of the Intergovernmental Panel on Climate Change; Intergovernmental Panel on Climate Change: Geneva, Switzerland, 2014.

6. Hirabayashi, Y.; Mahendran, R.; Koirala, S.; Konoshima, L.; Yamazaki, D.; Watanabe, S.; Kim, H.; Kanae, S. Global flood risk under climate change. Nat. Clim. Chang. 2013, 3, 816-821. [CrossRef]

7. Asadieh, B.; Krakauer, N.Y. Global change in streamflow extremes under climate change over the 21st century. Hydrol. Earth Syst. Sci. 2017, 21, 5863-5874. [CrossRef]

8. Sillmann, J.; Roeckner, E. Indices for extreme events in projections of anthropogenic climate change. Clim. Chang. 2008, 86, 83-104. [CrossRef] 
9. Zhang, Y.; Zhang, Y.; Shi, K.; Yao, X. Research development, current hotspots, and future directions of water research based on MODIS images: A critical review with a bibliometric analysis. Environ. Sci. Pollut. Res. 2017, 24, 15226-15239. [CrossRef]

10. Du, T.; Kang, S.; Zhang, J.; Davies, W.J. Deficit irrigation and sustainable water-resource strategies in agriculture for China's food security. J. Exp. Bot. 2015, 66, 2253-2269. [CrossRef] [PubMed]

11. Gosling, S.N.; Arnell, N.W. A global assessment of the impact of climate change on water scarcity. Clim. Chang. 2016, 134, 371-385. [CrossRef]

12. Mancosu, N.; Snyder, R.L.; Kyriakakis, G.; Spano, D. Water scarcity and future challenges for food production. Water 2015, 7, 975-992. [CrossRef]

13. WHO. COP24 Special Report: Health and Climate Change; World Health Organization: Geneva, Switzerland, 2018.

14. FAO. Water Management in Fragile Systems: Building Resilience to Shocks and Protracted Crises in the Middle East and North Africa; 9251306141; The World Bank: Washington, DC, USA, 2018.

15. Vermeulen, S.J.; Aggarwal, P.K.; Ainslie, A.; Angelone, C.; Campbell, B.M.; Challinor, A.J.; Hansen, J.W.; Ingram, J.; Jarvis, A.; Kristjanson, P. Options for support to agriculture and food security under climate change. Environ. Sci. Policy 2012, 15, 136-144. [CrossRef]

16. Al Zawad, F.M.; Aksakal, A. Impacts of climate change on water resources in Saudi Arabia. In Global Warming; Springer: Berlin/Heidelberg, Germany, 2010; pp. 511-523.

17. Haque, M.I.; Khan, M.R. Impact of climate change on food security in Saudi Arabia: A roadmap to agriculture-water sustainability. J. Agribus. Dev. Emerg. Econ. 2020, online ahead of print. [CrossRef]

18. Almazroui, M.; Islam, M.N.; Jones, P.; Athar, H.; Rahman, M.A. Recent climate change in the Arabian Peninsula: Seasonal rainfall and temperature climatology of Saudi Arabia for 1979-2009. Atmos. Res. 2012, 111, 29-45. [CrossRef]

19. Williams, J.B.; Shobrak, M.; Wilms, T.M.; Arif, I.A.; Khan, H.A. Climate change and animals in Saudi Arabia. Saudi J. Biol. Sci. 2012, 19, 121-130. [CrossRef] [PubMed]

20. Chowdhury, S.; Al-Zahrani, M. Implications of climate change on water resources in Saudi Arabia. Arab. J. Sci. Eng. 2013, 38, 1959-1971. [CrossRef]

21. Gosling, S.N.; Dunn, R.; Carrol, F.; Christidis, N.; Fullwood, J.; Gusmao, D.D.; Golding, N.; Good, L.; Hall, T.; Kendon, L. Climate: Observations, Projections and Impacts; The Met Office: Exeter, UK, 2011.

22. Tarawneh, Q.Y.; Chowdhury, S. Trends of climate change in Saudi Arabia: Implications on water resources. Climate 2018, 6, 8. [CrossRef]

23. Almazroui, M.; Islam, M.N.; Balkhair, K.S.; Şen, Z.; Masood, A. Rainwater harvesting possibility under climate change: A basin-scale case study over western province of Saudi Arabia. Atmos. Res. 2017, 189, 11-23. [CrossRef]

24. Samad, N.A.; Bruno, V.L. The urgency of preserving water resources. Environ. News 2013, 21, 3-6.

25. Luo, T.; Young, R.; Reig, P. Aqueduct Projected Water Stress Country Rankings; World Resources Institute: Washington, DC, USA, 2015.

26. Allbed, A.; Kumar, L.; Shabani, F. Climate change impacts on date palm cultivation in Saudi Arabia. J. Agric. Sci. 2017, 155, 1203-1218. [CrossRef]

27. Alkolibi, F.M. Possible effects of global warming on agriculture and water resources in Saudi Arabia: Impacts and responses. Clim. Chang. 2002, 54, 225-245. [CrossRef]

28. Alam, J.B.; Hussein, M.H.; Magram, S.F.; Barua, R. Impact of climate parameters on agriculture in Saudi Arabia: Case study of selected crops. Int. J. Clim. Chang. Impacts Responses 2011, 2, 41-50. [CrossRef]

29. Zatari, T.M. Second National Communication: Kingdom of Saudi Arabia; Presidency of Meteorology and Environment (PME): Jeddah, Saudi Arabia, 2011.

30. MEWA. National Environmental Strategy: Executive Summary for the Council of Economic and Development Affairs; Ministry of Environment, Water and Agriculture: Riyadh, Saudi Arabia, 2017.

31. Darfaoui, E.; Assiri, A. Response to Climate Change in the Kingdom of Saudi Arabia; Food and Agriculture Organization: Cairo, Egypt, 2009.

32. Zaid, A.; Arias-Jimenez, E.J. Date Palm Cultivation; Food and Agriculture Organization: Rome, Italy, 2002.

33. Nelson, G.C.; Rosegrant, M.W.; Koo, J.; Robertson, R.; Sulser, T.; Zhu, T.; Ringler, C.; Msangi, S.; Palazzo, A.; Batka, M. Climate Change: Impact on Agriculture and Costs of Adaptation; 0896295354; International Food Policy Research Institute: Washington, DC, USA, 2009; p. 30.

34. Sowers, J.; Vengosh, A.; Weinthal, E. Climate change, water resources, and the politics of adaptation in the Middle East and North Africa. Clim. Chang. 2011, 104, 599-627. [CrossRef]

35. Abd El-Hamid, H.T.; Hafiz, M.A.; Wenlong, W.; Qiaomin, L. Detection of environmental degradation in Jazan region on the Red Sea, KSA, Using mathematical treatments of remote sensing data. Remote Sens. Earth Syst. Sci. 2019, 2, 183-196. [CrossRef]

36. UNDP. Adaptation Policy Frameworks for Climate Change: Developing Strategies, Policies and Measures; United Nations Development Program, Cambridge University Press: Cambridge, UK, 2004.

37. Alotaibi, B.A.; Kassem, H.S.; Nayak, R.K.; Muddassir, M. Farmers' Beliefs and Concerns about Climate Change: An Assessment from Southern Saudi Arabia. Agriculture 2020, 10, 253. [CrossRef] 
38. Rosa, E.A. The logical structure of the social amplification of risk framework (SARF): Metatheoretical foundations and policy implications. In The Social Amplification of Risk; Pidgeon, N.F., Kasperson, R.E., Slovic, P., Eds.; Cambridge University Press: Cambridge, UK, 2003; pp. 47-79.

39. Maibach, E.W.; Leiserowitz, A.; Roser-Renouf, C.; Mertz, C.K. Identifying likeminded audiences for global warming public engagement campaigns: An audience segmentation analysis and tool development. PLoS ONE 2011, 6, e17571. [CrossRef]

40. Metag, J.; Füchslin, T.; Schäfer, M.S. Global warming's five Germanys: A typology of Germans' views on climate change and patterns of media use and information. Public Underst. Sci. 2015, 26, 434-451. [CrossRef] [PubMed]

41. Hine, D.W.; Reser, J.P.; Phillips, W.; Cooksey, R.; Marks, A.D.; Nunn, P.; Watt, S.E.; Bradley, G.L.; Glendon, I. Identifying climate change interpretive communities in a large Australian sample. J. Environ. Psychol. 2013, 36, 229-239. [CrossRef]

42. Howe, P.D.; Mildenberger, M.; Marlon, J.R.; Leiserowitz, A. Geographic variation in opinions on climate change at state and local scales in the USA. Nat. Clim. Chang. 2015, 5, 596-603. [CrossRef]

43. Capstick, S.; Whitmarsh, L.; Poortinga, W.; Pidgeon, N.; Upham, P. International trends in public perceptions of climate change over the past quarter century. Wiley Interdiscip. Rev. Clim. Chang. 2015, 6, 35-61. [CrossRef]

44. van der Linden, S. The social-psychological determinants of climate change risk perceptions: Towards a comprehensive model. J. Environ. Psychol. 2015, 41, 112-124. [CrossRef]

45. Kellstedt, P.M.; Zahran, S.; Vedlitz, A. Personal efficacy, the information environment, and attitudes toward global warming and climate change in the United States. Risk Anal. 2008, 28, 113-126. [CrossRef]

46. Heath, Y.; Gifford, R. Free-market ideology and environmental degradation the case of belief in global climate change. Environ. Behav. 2006, 38, 48-71. [CrossRef]

47. Malka, A.; Krosnick, J.A.; Langer, G. The association of knowledge with concern about global warming: Trusted information sources shape public thinking. Risk Anal. 2009, 9, 633-647. [CrossRef]

48. Milfont, T.L. The interplay between knowledge, perceived efficacy, and concern about global warming and climate change: A one-year longitudinal study. Risk Anal. 2012, 32, 1003-1020. [CrossRef]

49. Hornsey, M.J.; Harris, E.A.; Bain, P.G.; Fielding, K.S. Meta-analyses of the determinants and outcomes of belief in climate change. Nat. Clim. Chang. 2016, 6, 622-626. [CrossRef]

50. Akerlof, K.; Maibach, E.W.; Fitzgerald, D.; Cedeno, A.Y.; Neuman, A. Do people "personally experience" global warming, and if so how, does it matter? Glob. Environ. Chang. 2013, 23, 81-91. [CrossRef]

51. Slimak, M.W.; Dietz, T. Personal values, beliefs, and ecological risk perception. Risk Anal. 2006, 26, 1689-1705. [CrossRef] [PubMed]

52. Smith, N.; Leiserowitz, A. The rise of global warming skepticism: Exploring affective image associations in the United States over time. Risk Anal. 2012, 32, 1021-1032. [CrossRef] [PubMed]

53. PME. Temperature and Rainfall Pattern of Jazan Region; Presidency of Meteorology and Environment (PME): Riyadh, Saudi Arabia, 2019.

54. Arbuckle, J.G.; Morton, L.W.; Hobbs, J. Farmer beliefs and concerns about climate change and attitudes toward adaptation and mitigation: Evidence from Iowa. Clim. Chang. 2013, 118, 551-563. [CrossRef]

55. Habtemariam, L.T.; Gandorfer, M.; Kassa, G.A.; Heissenhuber, A. Factors influencing smallholder farmers' climate change perceptions: A study from farmers in Ethiopia. Environ. Manag. 2016, 58, 343-358. [CrossRef]

56. Thieken, A.H.; Kreibich, H.; Müller, M.; Merz, B. Coping with floods: Preparedness, response and recovery of flood-affected residents in Germany in 2002. Hydrol. Sci. J. 2007, 52, 1016-1037. [CrossRef]

57. Lindell, M.K.; Hwang, S.N. Households' perceived personal risk and responses in a multihazard environment. Risk Anal. 2008, 28, 539-556. [CrossRef]

58. Kellens, W.; Zaalberg, R.; Neutens, T.; Vanneuville, W.; De Maeyer, P. An analysis of the public perception of flood risk on the Belgian coast. Risk Anal. 2011, 31, 1055-1068. [CrossRef]

59. Seifert, I.; Botzen, W.W.; Kreibich, H.; Aerts, J.C. Influence of flood risk characteristics on flood insurance demand: A comparison between Germany and the Netherlands. Nat. Hazards Earth Syst. Sci. 2013, 13, 1691-1705. [CrossRef]

60. Abbas, A.; Amjath-Babu, T.; Kächele, H.; Müller, K. Participatory adaptation to climate extremes: An assessment of households' willingness to contribute labor for flood risk mitigation in Pakistan. J. Water Clim. Chang. 2016, 7, 621-636. [CrossRef]

61. Arbuckle, J.G.; Morton, L.W.; Hobbs, J. Understanding farmer perspectives on climate change adaptation and mitigation: The roles of trust in sources of climate information, climate change beliefs, and perceived risk. Environ. Behav. 2015, 47, 205-234. [CrossRef]

62. Mataya, D.C.; Vincent, K.; Dougill, A.J. How can we effectively build capacity to adapt to climate change? Insights from Malawi. Clim. Dev. 2020, 12, 781-790. [CrossRef]

63. Allen, K. Vulnerability Reduction and the Community-based Approach: A Philippines Study. In Natural Disasters and Development in a Globalizing World; Pelling, M., Ed.; Routledge: London, UK, 2003; pp. 170-184.

64. Allen, K. Community-based disaster preparedness and climate adaptation: Local capacity-building in the Philippines. Disasters 2006, 30, 81-101. [CrossRef]

65. Cooper, P.; Poe, G.L.; Bateman, I.J. The structure of motivation for contingent values: A case study of lake water quality improvement. Ecol. Econ. 2004, 50, 69-82. [CrossRef]

66. Farizo, B.A.; Oglethorpe, D.; Soliño, M. Personality traits and environmental choices: On the search for understanding. Sci. Total Environ. 2016, 566, 157-167. [CrossRef] 
67. Grothmann, T.; Reusswig, F. People at risk of flooding: Why some residents take precautionary action while others do not. Nat. Hazards 2006, 38, 101-120. [CrossRef]

68. Casaló, L.V.; Escario, J.-J. Heterogeneity in the association between environmental attitudes and pro-environmental behavior: A multilevel regression approach. J. Clean. Prod. 2018, 175, 155-163. [CrossRef]

69. Peacock, W.G.; Brody, S.D.; Highfield, W. Hurricane risk perceptions among Florida's single family homeowners. Landsc. Urban Plan. 2005, 73, 120-135. [CrossRef]

70. Rungie, C.; Scarpa, R.; Thiene, M. The influence of individuals in forming collective household preferences for water quality. J. Environ. Econ. Manag. 2014, 68, 161-174. [CrossRef]

71. Melo, P.C.; Ge, J.; Craig, T.; Brewer, M.J.; Thronicker, I. Does work-life balance affect pro-environmental behaviour? Evidence for the UK using longitudinal microdata. Ecol. Econ. 2018, 145, 170-181. [CrossRef]

72. Grønhøj, A.; Thøgersen, J. Like father, like son? Intergenerational transmission of values, attitudes, and behaviours in the environmental domain. J. Environ. Psychol. 2009, 29, 414-421. [CrossRef]

73. Miceli, R.; Sotgiu, I.; Settanni, M. Disaster preparedness and perception of flood risk: A study in an alpine valley in Italy. J. Environ. Psychol. 2008, 28, 164-173. [CrossRef]

74. Botzen, W.; Aerts, J.; Van Den Bergh, J. Dependence of flood risk perceptions on socioeconomic and objective risk factors. Water Resour. Res. 2009, 45, W10440. [CrossRef]

75. Hasan, S.S.; Deng, X.; Li, Z.; Chen, D. Projections of future land use in Bangladesh under the background of baseline, ecological protection and economic development. Sustainability 2017, 9, 505. [CrossRef]

76. Alauddin, M.; Sarker, M.A.R. Climate change and farm-level adaptation decisions and strategies in drought-prone and groundwater-depleted areas of Bangladesh: An empirical investigation. Ecol. Econ. 2014, 106, 204-213. [CrossRef]

77. Aryal, J.P.; Sapkota, T.B.; Rahut, D.B.; Krupnik, T.J.; Shahrin, S.; Jat, M.L.; Stirling, C.M. Major climate risks and adaptation strategies of smallholder farmers in coastal Bangladesh. Environ. Manag. 2020, 66, 105-120. [CrossRef] [PubMed]

78. Li, F.W.; Lin, Y.; Jin, Z.; Zhang, Z. Do firms adapt to climate change? Evidence from establishment-level data. In Research Collection Lee Kong Chian School Of Business; Elsevier: Singapore, 2020; pp. 1-42.

79. Mahmood, N.; Arshad, M.; Kächele, H.; Ullah, A.; Müller, K. Economic efficiency of rainfed wheat farmers under changing climate: Evidence from Pakistan. Environ. Sci. Pollut. Res. 2020, 27, 34453-34467. [CrossRef]

80. Leiserowitz, A. International Public Opinion, Perception, and Understanding of Global Climate Change; Human Development Report 2007/2008; United Nations Development Programme: New York, NY, USA, 2007.

81. Weber, E.U.; Stern, P.C. Public understanding of climate change in the United States. Am. Psychol. 2011, 66, 315-328. [CrossRef] [PubMed]

82. Fonta, W.M.; Sanfo, S.; Kedir, A.M.; Thiam, D.R. Estimating farmers' willingness to pay for weather index-based crop insurance uptake in West Africa: Insight from a pilot initiative in Southwestern Burkina Faso. Agric. Food Econ. 2018, 6, 11. [CrossRef]

83. Iqbal, M.A.; Abbas, A.; Naqvi, S.A.A.; Rizwan, M.; Samie, A.; Ahmed, U.I. Drivers of Farm Households' Perceived Risk Sources and Factors Affecting Uptake of Mitigation Strategies in Punjab Pakistan: Implications for Sustainable Agriculture. Sustainability 2020, 12, 9895. [CrossRef]

84. Keshavarz, M.; Karami, E. Farmers' pro-environmental behavior under drought: Application of protection motivation theory. J. Arid Environ. 2016, 127, 128-136. [CrossRef]

85. Whitmarsh, L. Behavioural responses to climate change: Asymmetry of intentions and impacts. J. Environ. Psychol. 2009, 29, 13-23. [CrossRef]

86. van der Linden, S.L.; Leiserowitz, A.A.; Feinberg, G.D.; Maibach, E.W. Thescientific consensus on climate change as a gateway belief: Experimental evidence. PLoS ONE 2015, 10, e0118489. [CrossRef] [PubMed]

87. Hirsh, J.B. Personality and environmental concern. J. Environ. Psychol. 2010, 30, 245-248. [CrossRef]

88. Ali, A.; Erenstein, O. Assessing farmer use of climate change adaptation practices and impacts on food security and poverty in Pakistan. Clim. Risk Manag. 2017, 16, 183-194. [CrossRef]

89. Daramola, A.Y.; Oni, O.T.; Ogundele, O.; Adesanya, A. Adaptive capacity and coping response strategies to natural disasters: A study in Nigeria. Int. J. Disaster Risk Reduct. 2016, 15, 132-147. [CrossRef]

90. Ding, Y.; Hayes, M.J.; Widhalm, M. Measuring economic impacts of drought: A review and discussion. Disaster Prev. Manag. 2011, 20, 434-446. [CrossRef]

91. Dai, A. Increasing drought under global warming in observations and models. Nat. Clim. Chang. 2013, 3, 52-58. [CrossRef]

92. Spinoni, J.; Naumann, G.; Carrao, H.; Barbosa, P.; Vogt, J. World drought frequency, duration, and severity for 1951-2010. Int. J. Climatol. 2014, 34, 2792-2804. [CrossRef]

93. Mubeen, M.; Iftikhar, Y.; Ullah, M.I.; Shakeel, Q.; Aatif, M.; Bilqees, I. Incidence of Okra Yellow Vein Mosaic disease in relation to insect vector and environmental factors. Environ. Ecol. 2017, 35, 2215-2220.

94. Workneh, F.; Narasimhan, B.; Srinivasan, R.; Rush, C.M. Potential of radar-estimated rainfall for plant disease risk forecast. Phytopathology 2005, 95, 25-27. [CrossRef] [PubMed]

95. Chakraborty, U.; Chakraborty, N. Impact of environmental factors on infestation of tea leaves by Helopeltis theivora, and associated changes in flavonoid flavor components and enzyme activities. Phytoparasitica 2005, 33, 88-96. [CrossRef]

96. Barros, V.R.; Boninsegna, J.A.; Camilloni, I.A.; Chidiak, M.; Magrín, G.O.; Rusticucci, M. Climate change in Argentina: Trends, projections, impacts and adaptation. Wiley Interdiscip. Rev. Clim. Chang. 2015, 6, 151-169. [CrossRef] 
97. Hunter, P.R. Climate change and waterborne and vector-borne disease. J. Appl. Microbiol. 2003, 94, 37-46. [CrossRef]

98. Adger, W.N.; Huq, S.; Brown, K.; Conway, D.; Hulme, M. Adaptation to climate change in the developing world. Prog. Dev. Stud. 2003, 3, 179-195. [CrossRef]

99. Pour, M.D.; Barati, A.A.; Azadi, H.; Scheffran, J. Revealing the role of livelihood assets in livelihood strategies: Towards enhancing conservation and livelihood development in the Hara Biosphere Reserve, Iran. Ecol. Indic. 2018, 94, 336-347. [CrossRef]

100. Gaillard, J.-C.; Mercer, J. From knowledge to action: Bridging gaps in disaster risk reduction. Prog. Hum. Geogr. 2013, 37, 93-114. [CrossRef]

101. Mercer, J.; Kelman, I.; Taranis, L.; Suchet-Pearson, S. Framework for integrating indigenous and scientific knowledge for disaster risk reduction. Disasters 2010, 34, 214-239. [CrossRef] [PubMed]

102. Adesina, A.A.; Mbila, D.; Nkamleu, G.B.; Endamana, D. Econometric analysis of the determinants of adoption of alley farming by farmers in the forest zone of southwest Cameroon. Agric. Ecosyst. Environ. 2000, 80, 255-265. [CrossRef]

103. Mwangi, M.; Kituyi, E.; Ouma, G. Enhancing adoption of climate services through an innovation systems approach. Sci. Afr. 2020, 8, e00445. [CrossRef]

104. Verbist, K.; Amani, A.; Mishra, A.; Cisneros, B.J. Strengthening drought risk management and policy: UNESCO International Hydrological Programme's case studies from Africa and Latin America and the Caribbean. Water Policy 2016, 18, $245-261$. [CrossRef] 